ISBN 978-81-933894-1-6

5th International Conference on Chemical, Agricultural, Biological and Environmental Sciences

(CAFES-17)

Kyoto (Japan) April 18-19, 2017

\title{
Growth of BRIS Soil Bacteria in Organic Material and Potassium Nitrate
}

\author{
Zakiah Mustapha ${ }^{1}$, Nashriyah Mat ${ }^{2}$, Radziah Othman ${ }^{3}$ and Abd Jamil Zakaria ${ }^{1}$ \\ ${ }^{1}$ Institute of Agricultural Production and Food Innovation (AGROPOLIS), Universiti Sultan Zainal Abidin, \\ Besut Campus, 22200 Besut, Terengganu, Malaysia. \\ ${ }^{2}$ Faculty of Bioresources and Food Industry (FBIM), Universiti Sultan Zainal Abidin, Besut Campus, 22200 \\ Besut, Terengganu, Malaysia. \\ ${ }^{3}$ Department of Land Management, Faculty of Agriculture, Universiti Putra Malaysia, 43400 Serdang, Malaysia.

\begin{abstract}
Three different bacterial strains namely UA 1, UAA 2 and UA 6 were isolated from rhizosphere of Acacia mangium on BRIS soil in Terengganu. These bacteria have possibility to fix nitrogen, solubilize phosphate and produce Indole Acetic Acid (IAA). Molasses medium enriched with fish meal increased bacterial growth from 18.07 to $112.77 \%$. The use of $2 \%$ fish meal gave the highest bacterial growth, but the use of $1 \%$ fish meal was economic enough as the growth difference was not significant. All bacterial strains were tolerance to high concentration of potassium nitrate $\left(\mathrm{KNO}_{3}\right)$ and UA 6 showed the highest growth from $\log _{10} 7.62 \mathrm{CFU} / \mathrm{ml}$ at day 0 to $\log _{10} 12.52 \mathrm{CFU} / \mathrm{mL}$ at day 6. This study shows that bacterial strains UA 1, UAA 2 and UA 6 had potential to be exploited and will be further studied.
\end{abstract}

Keywords: bacteria, biochemical, BRIS soil, fish meal, potassium nitrate

\section{Introduction}

Bacteria constitutes a large domain of prokaryotic microorganisms that exist everywhere including in soil. Bacteria plays a vital role in many aspects especially in recycling nutrients such as fixation of nitrogen from the atmosphere and solubilizing inorganic phosphorus from insoluble compounds that are crucial for plant growth and yield. The natural process of biological nitrogen fixation from the atmosphere is mediated by the microorganism that can be classified as symbiotic and non- symbiotic or free living forms [1]. Rhizobium is the prominent $\mathrm{N}$-fixer symbiotic microorganism with the leguminous plants while free-living bacteria and blue green algae are mostly the non-symbiotic type. Most of the essential plant nutrients including phosphorus remain in insoluble form in soil that make them unavailable to plants [2]. It needs to be released and phosphatesolubilizing bacteria can improve solubilization of fixed soil phosphorus and applied phosphates.

High temperature and dry condition of BRIS soil give the adverse effects on diversity, growth and maintainers of beneficial soil microorganisms. BRIS (Beach Ridges Interspersed with Swales) is the sandy soil that originates from sediment or sand from the erosion of layers of steep cliffs by the sea during the monsoon seasons and has a coarse sand component [3]. This type of soil is distributed along the east coast of Peninsular Malaysia (Kelantan, Terengganu and Pahang) and right down along the coast to the west coast of Johor [4]. It contents more than $95 \%$ sand caused the excessive drainage, low moisture and nutrient content and high soil temperature of up to $42^{\circ} \mathrm{C}$ had caused limited ability to support plant growth thus, make it as problematic soil $[5,6]$.

All bacteria require the right condition and nutrients to grow. High level of nutrients in solid or liquid media are mostly used to grow large amount of bacteria. These chemically defined media are widely used for 
laboratory needs but could be costly for commercial purpose such as in effective microbes (EM) based fertilizer industry. Molasses is one of other organic materials that is used as the carbon and nitrogen sources for bacterial growth. It consists of a few types and sugar cane molasses has been reported to be used as the growth medium of several bacteria and other microorganisms. Sugarcane molasses is made by boiling its extracted juice until crystallization. Since microbes grow more vigorously on complex media then in mineral media, the addition of other organic materials such as fish meal could be effective. Fish meal is the commercial product in powder or cake form that is made by drying and grinding the fish. It has high protein composition that plays an important role for bacterial metabolism as well as plant growth and development.

The effective microorganisms (EM) based organic fertilizer are widely used today. It could improve crop growth and yield, not harmful to the life form and also friendly to the environment. In the market, most of EM fertilizer and chemical fertilizer are sold separately. It is because the concentrated chemical mixture such as foliar fertilizer is not suitable to be inoculated with EM. High concentration of chemicals such as potassium nitrate $\left(\mathrm{KNO}_{3}\right)$ could increase salinity causing the hyper osmotic stress that could contribute to the death of bacterial cell.

\section{Materials and Methods}

\subsection{Soil Sampling and Isolation of rhizospheric bacterial}

Soil samples were collected from the rhizosphere of Acacia tree (Acacia mangium) at the Apiary of Tembila Campus, UniSZA. Five random samples from plant's rhizosphere were withdrawn from 10-15 cm soil depth. The soil samples were air dried and passed through a $2 \mathrm{~mm}$ sieve before being mixed into a single composite sample. Ten grams of BRIS soil was suspended in $90 \mathrm{~mL}$ sterile saline water, rotary shaked at 150 $\mathrm{rpm}$ for one hour at room temperature $\left(28 \pm 2{ }^{\circ} \mathrm{C}\right)$ and serially diluted. One $\mathrm{mL}$ of aliquots from dilutions $10^{-4}$ until $10^{-6}$ were inoculated in $99 \mathrm{~mL}$ nitrogen free media (Burk's broth medium) for three days prior to plating on Pikovskaya's (PVK) medium for seven days at room temperature $\left(28 \pm 2{ }^{\circ} \mathrm{C}\right)$ for isolation of bacteria that has both abilities to fix nitrogen and solubilize phosphate. Pure colonies were obtained by repeated streaking on PVK medium. Eight colonies that showed different morphology were isolated and from the results of gram staining, three colonies labelled as UA 1, UAA 2 and UA 6 were finally isolated and subcultured for further analysis.

\subsection{Biochemical characterization of bacterial isolates}

Biochemical characters of bacterial isolates were examined according to methods described [7]. The isolates were characterized for the following traits on nutrient agar: colony size, color, pigmentation, opacity, form and margin. The Gram reaction was performed as per standard procedure. Oxidase reaction, catalase test and indole test were performed according to standard methods [8].

\subsection{Effect of Fish Meal on Bacterial Growth}

The isolated bacteria in the nutrient broth media was used as the inoculum. The optical density of the cell suspension was adjusted around $0.4 \mathrm{~A}$ at $600 \mathrm{~nm}$ using UV-VIS spectrophotometer (approximately $4 \times 10^{7}$ cells $/ \mathrm{mL}$ ) and $1 \mathrm{~mL}$ was inoculated to $500 \mathrm{~mL}$ medium. Distilled water and molasses at ratio of 18:1 was used as the basal medium for propagation and further analysis of the selected bacteria. Fish meal at different concentrations $(0,0.25,0.5,1$ and $2 \%)$ were added to the medium and sterilized. Exactly, $0.5 \mathrm{~mL}$ of bacterial inoculum were added to $250 \mathrm{~mL}$ molasses media, incubated at room temperature $\left(28 \pm 2{ }^{\circ} \mathrm{C}\right)$ and rotary shaking at $150 \mathrm{rpm}$ for five days. The number of viable cells were determined and the results were given as CFU/mL.

\subsection{Effects of Potassium Nitrate on Bacterial Growth}

Molasses media supplemented with $1 \%$ fish meal and different concentrations of $\mathrm{KNO}_{3}(0,2,4,8$ and 16

$\%)$ were prepared. Inoculation was done and the cultures were incubated at room temperature $\left(28 \pm 2{ }^{\circ} \mathrm{C}\right)$ and rotary shaking at $150 \mathrm{rpm}$ for 12 days. The number of viable cells were determined and the results were given as $\mathrm{CFU} / \mathrm{mL}$. 


\section{Results and Discussion}

Three strains of bacteria were isolated from BRIS soil and consequently labelled as UA 1, UAA 2, and UA 6. These strains were isolated based on different colony morphology that dominate on the PVK agar medium. All strains considered have both abilities to fix nitrogen and solubilize phosphate as they grow abundantly on Burk's medium and PVK medium. Burk's medium is recommended for detection of nitrogen fixing organisms from soil [9]. This medium lacks nitrogen source and the bacteria that can grow on this medium utilizes atmospheric nitrogen gas for their cell protein synthesis. The plate assay method using PVK agar are routinely used to screen for phosphate solubilizing microorganisms [10]. Phosphate solubilizing bacteria will grow on this medium and form a halo zone around the colony due to phosphate solubilized by them.

Gram staining test showed that two strains (UA 1 and UAA 2) were gram negative with coccus and rod shape respectively while UA 6 was gram positive in rod shape. The biochemical traits as described in Table 1 showed that all strains were definitely from different types of isolates. It also showed that strains UA 1 and UA 6 gave a positive results in indole test meaning that they can convert tryptophan to indole that regulates various aspects of bacterial physiology.

TABLE 1: Biochemical reaction result of BRIS soil bacteria.

\begin{tabular}{llll}
\hline \hline & UA 1 & UAA 2 & UA 6 \\
\hline Gram staining & Negative & Negative & Positive \\
Cell Shape & Coccus & Rod & Rod \\
Size $(m m)$ & Pinpoint & Moderate & Large \\
Color & Creamy white & Creamy white & Creamy white \\
Pigment & Negative & Negative & Negative \\
Opacity & Opaque & Opaque & Opaque \\
Form & Circular & Circular & Irregular \\
Margin & Entire & Entire & Undulate \\
Catalase & Positive & Positive & Positive \\
Oxidase & Positive & Negative & Positive \\
Indole & Positive & Negative & Positive \\
& & & \\
\hline \hline
\end{tabular}

Fish meal has shown a significant result when added to the molasses medium. Additions of $0.25,0.5,1$ and $2 \%$ fish meal had increased the growth of all bacterial strains from 18.07 to $112.77 \%$. Bacterial growth was increased as the fish meal percentage was increased (Figure 1). The use of 1 and $2 \%$ fish meal did not show much difference in UA 1 and UAA 2 but the results were significant for UA 6 . Fish meal has been used as a soil amendment with great success in vegetable production systems [11], and plants respond to and grow vigorously when regularly fertilized with fish fertilizer [12]. Organic fertilizer improves the physical structure of soil which allows more air to get into plants roots and also increase bacterial and fungal activities in the soil [12]. Molasses might have contributed better growth due to the presence of other nutrients. Cane molasses used as carbon source contain $60 \%$ sucrose in addition to growth promoting components [13]. Therefore, molasses medium could be an effective and economic way to propagate bacteria. 


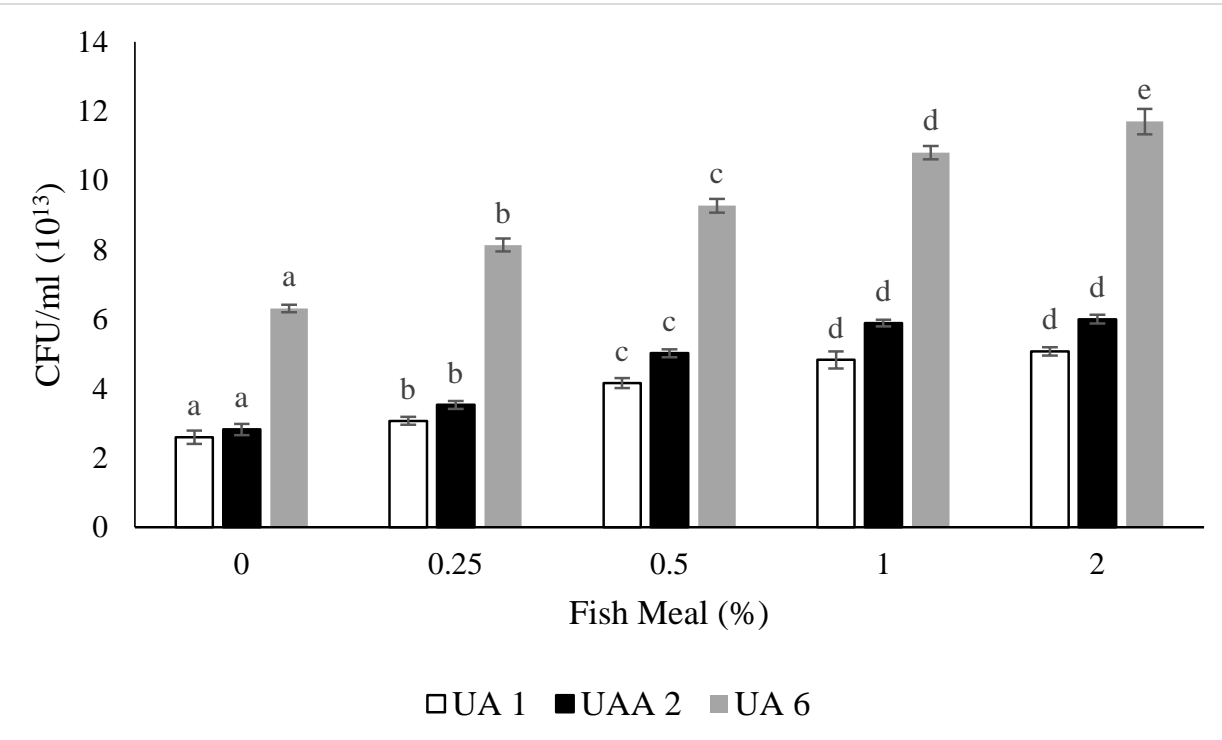

Fig 1: Growth of BRIS soil bacteria in different concentrations of fish meal in molasses medium. Data were given as mean $\pm \mathrm{SD}$ at $\mathrm{p} \leq 0.05$ Tukey's multiple comparison, $\mathrm{n}=4$.

Potassium nitrate $\left(\mathrm{KNO}_{3}\right)$ is the ionic salt of potassium $\left(\mathrm{K}^{+}\right)$and nitrate $\left(\mathrm{NO}^{-}\right)$that was added into fertilizer mixture for the healthy growth of plants and formation of flowers and fruits. The use of excessive fertilizer in agriculture will eventually increase soil salinity that might affect plant growth and soil microbial functions. Figure 2 shows the effects of $\mathrm{KNO}_{3}$ on bacterial growth in molasses medium. It was obvious that increasing $\mathrm{KNO}_{3}$ percentage caused reduced growth of all strains. However, all strains managed to survive and grow in every treatments (Figure 2). At $16 \% \mathrm{KNO}_{3}$, growth curves for UA 1 and UAA 2 were almost similar while UA 6 showed quite a high growth rate (Figure 3). Growth of UA 6 at day six was $\log _{10} 12.52$ that is almost four times higher than UA $1\left(\log _{10} 8.70\right)$ and UAA $2\left(\log _{10} 8.94\right)$ in that particular medium. Increasing $\mathrm{KNO}_{3}$ percentage means that increasing the medium salinity and reduction of bacterial growth rate. Salinity reduce microbial biomass because of the osmotic stress, resulting in the drying and lysis of cells [14]. Even though plant and microbes could adapt to low osmotic potential by accumulating osmolytes, this process requires large amount of energy and this resulted in reduced growth and activity [15].

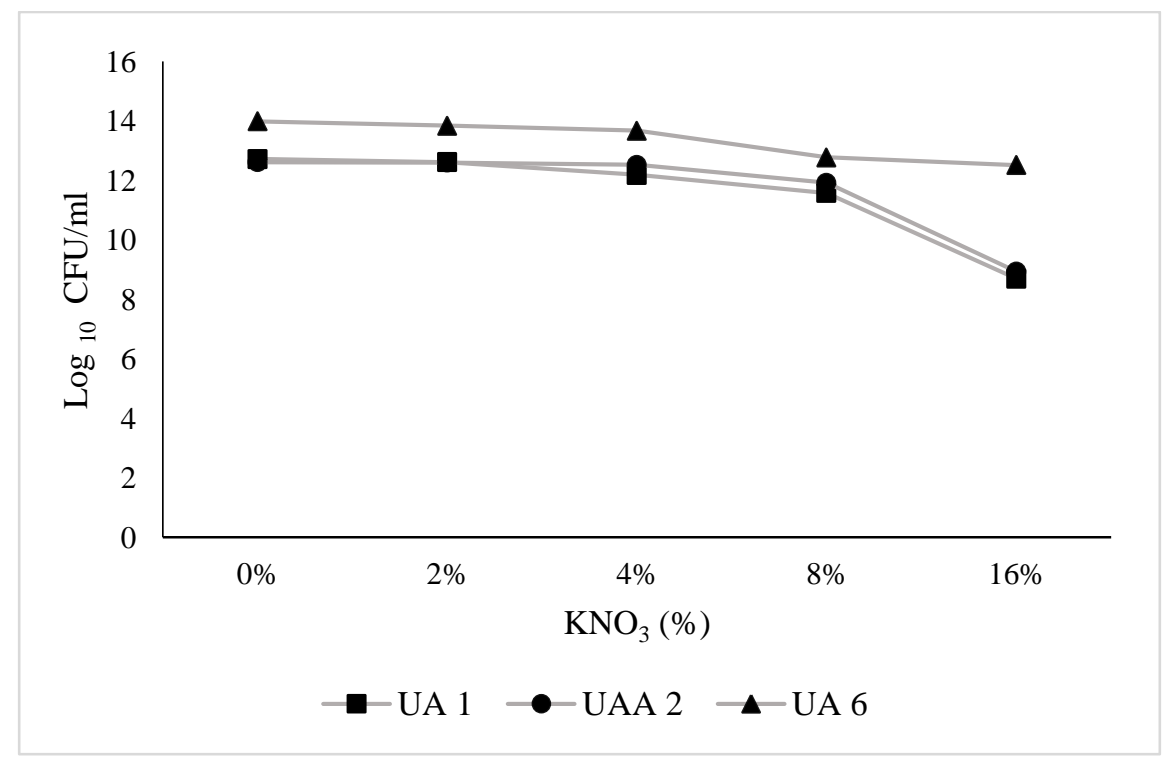

Fig 2: Growth of BRIS soil bacteria in different concentrations of potassium nitrate in molasses medium. Data were given as mean $\pm S D, n=4$. 


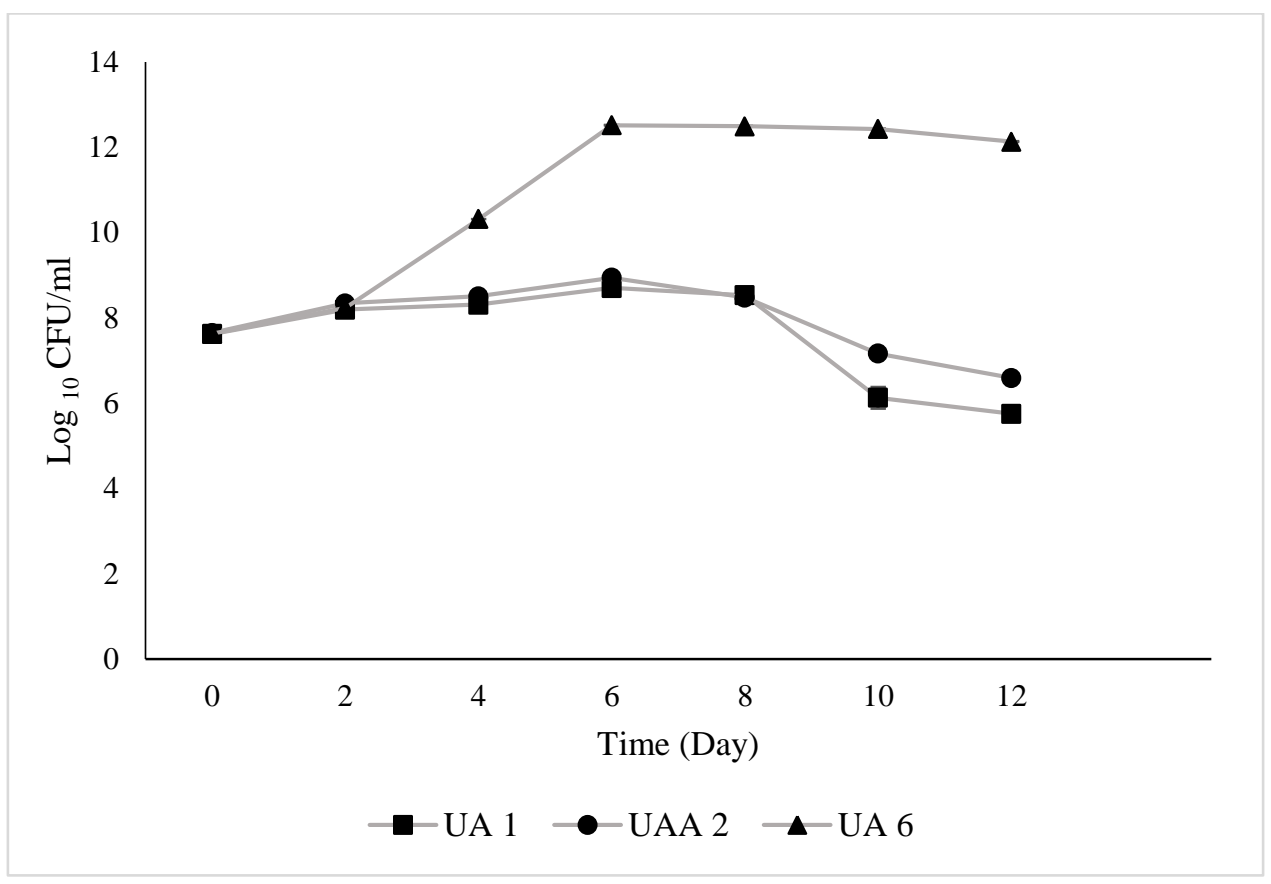

Fig 3: Growth of BRIS soil bacteria in molasses medium with $16 \%$ potassium nitrate. Data were given as mean $\pm \mathrm{SD}, \mathrm{n}=4$.

\section{Conclusion}

There are still abundant of bacteria in BRIS soil even though that type of soil is considered as problematic soil. This study has successfully isolated three types of bacteria namely UA 1, UAA 2 and UA 6 that have both abilities to fix nitrogen and solubilize phosphate and also in producing IAA. The use of molasses medium supplemented with fish meal could increase bacterial growth. This finding suggested that molasses and fish meal are the organic materials that can be used as the alternative and more economic bacterial growth media. Increasing $\mathrm{KNO}_{3}$ in medium will reduce bacterial growth. However, the three strains are managed to grow at $16 \% \mathrm{KNO}_{3}$ meaning that they are tolerant to high salinity. UA 1, UAA 2 and UA 6 have potentials to be used in improving soil fertility for plant growth or in fertilizer industry. Identification of these bacterial strains at molecular level, as well as quantitative estimation of nitrogen fixing, solubilizing phosphate and production of IAA will be further studied.

\section{Acknowledgement}

The authors are thankful to Universiti Sultan Zainal Abidin (UniSZA) in particular the Institute of Agricultural Production and Food Innovation (AGROPOLIS) UniSZA and the Faculty of Bioresources and Food Industry (FBIM), UniSZA as well as the Ministry of Higher Education Malaysia for the KTP-Community grant KTP/Bil 003/16 (KTP-R5)

\section{References}

[1] H. Dalton, "The cultivation of diazotrophic microorganisms," in Methods for Evaluating Biological Nitrogen Fixation, F.J. Bergersen, Ed. Chichester: John Wiley \& Sons, 1980, pp. 13-64.

[2] K.S. Yadav and K.R. Dadarwal. "Phosphate solubilisation and mobilization through soil microorganisms," in Biotechnological Approaches in Soil Microorganisms for Sustainable Crop Production, K.R. Dadarwal. Ed. Jodhpur: Scientic Publishers, 1997, pp. 293-308. 
[3] J. J. Nossin, "Beach Ridges of the East Coast of Malaya," Tropical Geography Journal, vol. 18, pp. 111-117, 1964.

[4] M. E. Toriman, M. Mokhtar, M.B Gazim and N. A. A Aziz, "Analysis of the Physical Characteristics of BRIS Soil in Coastal Kuala Kemaman, Terengganu," Research Journal of Earth Science, 1 (1), pp. 01-06, 2009.

[5] M. M. Hanafiah, J. H. Adam, M. B. Gasim, S. A. Rahin and N. E. Muslim, "Pengurusan dan pemuliharaan tanah bris untuk aktiviti pertanian di Marang Terengganu," in KUSTEM Third Annual Seminar on Sustainability Science and Management, N. M Tahir, N. M. Amin and K. Yunus, Eds. Kuala Terengganu: Kolej Universiti Sains dan Teknologi Malaysia, 2004, pp. 265-268.

[6] N. E. Muslim, J. H. Adam, M. B. Gasim, S. A. Rahin and M. M. Hanafiah, "Sifat dan taburan tanah BRIS di Kemaman Terengganu," in KUSTEM Third Annual Seminar on Sustainability Science and Management, N. M Tahir, N. M. Amin and K. Yunus, Eds. Kuala Terengganu: Kolej Universiti Sains dan Teknologi Malaysia, 2004, pp. 265-268.

[7] G. H. John, N. R. Kreig, H. A. P. Smeath, J. T. Staley and S. T. Williams, "Bergey's Manual of Determinative of Bacteriology", $9^{\text {th }}$ ed. Baltimore, U.S.A.: The Williams and Wilkins Co., 1994, pp. 605-702.

[8] S. A. Gordon and R. P. Weber, "Colorimetric Estimation of Indole-Acetic Acid," Plant Physiology, vol. 18, pp. 192195, 1951.

https://doi.org/10.1104/pp.26.1.192

[9] N. S. Subba Rao, "Soil Microorganisms and Plant Growth,” New Delhi: Oxford \& IBH Publishing Co. 1997, pp. 254255.

[10]R. I. Pikovskaya, "Mobilization of Phosphorus in Soil in Connection with the Vital Activity of some Microbial Species," Microbiologiya, vol. 17, pp. 362-370, 1948.

[11]C. R. Blatt and K. B. Mc. Rae, "Comparison of Four Organic Amendments With a Chemical Fertilizer Applied to Three Vegetables in Rotation,” Can. J. Plant Sci, vol. 78, pp. 641-646, 1998. https://doi.org/10.4141/P97-089

[12] A. Lema and A. Degebassa, "Comparison of Chemical Fertilizer, Fish Offal's Fertilizer and Manure applied to Tomato and Onion,” African Journal of Agricutural Research, vol. 8(3), pp. 274-278, 2013.

[13] R.P. Jones, N. Pamment and P.F. Greenfield, "Alcohol Fermentation by Yeasts. The Effect of Environmental and Other Variables," Proc. Biochem, vol. 16, pp. 42-45. 1981.

[14]B. C. Yuan, Z. Z. Li, H. Liu, M. Gao and Y. Y. Zhang, “ Microbial Biomass and Activity in Salt Affected Soil Under Arid Conditions," Applied Soilless Ecology, vol. 35, pp. 319-328, 2007.

https://doi.org/10.1016/j.apsoil.2006.07.004

[15] J. Wichern, F. Wichern and R. G. Joergensen, "Impact of Salinity on Soil Microbial Communities and the Decomposition of Maize in Acidic soils," Geoderma, vol. 137, pp. 100-108, 2006.

https://doi.org/10.1016/j.geoderma.2006.08.001 